\title{
Asparaginase Antibody
}

National Cancer Institute

\section{Source}

National Cancer Institute. Asparaginase Antibody. NCI Thesaurus. Code C129659.

Any immunog lobulin that recognizes asparaginase. 